\title{
Application of the Mind Map in Learning English Vocabulary
}

\author{
Yushan Jiang \\ School of Foreign Languages, East China University of Science and Technology, Shanghai, China \\ Email:jiangyushan33@163.com
}

How to cite this paper: Jiang, Y.S. (2020) Application of the Mind Map in Learning English Vocabulary. Open Access Library Journal, 7: e6484.

https://doi.org/10.4236/oalib.1106484

Received: May 29, 2020

Accepted: June 21, 2020

Published: June 24, 2020

Copyright () 2020 by author(s) and Open Access Library Inc.

This work is licensed under the Creative Commons Attribution International License (CC BY 4.0).

http://creativecommons.org/licenses/by/4.0/

\begin{abstract}
Memorizing new vocabularies has always been a difficult task for English language learners. With the help of mind maps, it would be more effective for students to improve vocabulary learning and knowledge management.

\section{Subject Areas}

Education

\section{Keywords}

Mind Map, Education, English Vocabulary, Covid-19
\end{abstract}

\section{Introduction}

After delaying the start of spring semester due to novel coronavirus outbreak, the Ministry of Education in China launched an initiative entitled "don't let the virus keep you from learning". As of March, the number of online education users in China had reached 423 million increasing by 110.2 percent compared with the end of 2018 [1]. But students seem to be less engaged in their courses after months of online study, especially when it comes to vocabulary learning by rote [2]. The mind-mapping strategy is considered to be helpful for students to associate new information with existing ones as well as finding interest in learning again. This article integrates mind-mapping into vocabulary learning with the example of coronavirus-related words.

\section{Application of the Mind Map in Vocabulary Learning}

\subsection{Mind Mapping}

The term "mind map" was popularized for the first time by Tony Buzan in 1960s. Since then, it has been an effective tool of learning, note-taking, brains- 
torming, visual thinking and problem solving in countless research fields including education, writing, project management, etc. [3]. The mind map, based on the radiant thinking pattern of our brains, is a tree-like structure diagramed with colorful and highly organized key words. A mind map cannot live without the following parts: first, the main idea is crystallized in the center of a mind map; second, branches radiating from the center are the main themes of the topic; third, key words or images that link the theme to the main idea are drawn on the branch lines; forth, secondary themes can be attached to the relevant branch as twigs; finally, all the branches and twigs together present a connected nodal structure. That's how students map out their ideas in a memorable and highly organized diagram.

As the key to unlock memories, mind mapping benefits students in many respects. First, it helps associate new information to prior knowledge [4]. Instead of rote learning, it forces students to find connections in their head that leads to meaningful learning. Second, it is an effective tool to figure out complex issues [5]. Once all the ideas are presented, they can be grouped and illustrated in a highly organized structure that gives students a deeper understanding than before. Third, mind mapping ignites creativity and makes learning more spontaneous, flexible and enjoyable. Students are allowed to empty out their heads once any ideas strike them.

\subsection{Mind Map of Coronavirus-Related Words}

Vocabularies in our brains are hooked into semantic networks like maps representing knowledge in patterns of interconnected nodes [6]. Thus mind mapping could support the teaching and learning of vocabularies through the visualization of related information. For example, "coronavirus" could be placed at the center of a mind map as the main topic being learned. Then, the branches radiated from the topic "coronavirus" could be a series of most discussed issues during the pandemic such as "what is the timeline of the coronavirus, how does it spread, and what are the symptoms of it". In this way, the secondary themes would be any words associated with the above questions.

Specifically, words or phrases we would think of when it comes to "the timeline of the coronavirus" could be "outbreak, epidemic and pandemic". They are also synonyms that students are probably confused about: "outbreak" refers to "the sudden start of something unpleasant especially violence or a disease", and it could be spread in one area or be extended more widely [7]; "epidemic" happens when "a large number of cases of a particular disease happening at the same time in a particular community", which usually infects more people than an outbreak [8]; and finally "pandemic" disease "spreads over a whole country or the whole world" [9]. While presenting the timeline associated with "coronavirus" on account of its illustration of the thinking process, "outbreak, epidemic and pandemic" could be regarded as twigs spreading out from the main theme. These new words would be logically connected with existing knowledge of Co- 
vid-19 in students' heads. At first, it started as an outbreak in Wuhan, Hubei province followed by the coronavirus epidemic in the Asia-Pacific region, and then it was declared as a global pandemic by the World Health Organization. In this way, mind mapping takes advantage of the existing logical relationship behind the global health emergency, and thus alleviates the burden of rote memorization in regard to the meaning and differences of new vocabularies.

In terms of the branch labeled "what are the symptoms of it", students would think of "cough, shortness of breath, fever, chills, muscle pain, sore throat, etc.". Other than logical thinking, colors or graphs, approaches more evocative than words, are considered to be useful in a mind map. In the process of constructing it, students could draw pictures of people coughing or having a fever. The visual impact could leverage powerful associative capabilities in our brains, and also ignite our interest of learning. Similarly, the theme labeled "how does it spread" could be illustrated by images as well. After sketching ideas associated with the theme such as droplets, airborne transmission and surface transmission, our brains would be better engaged than mere texts. Altogether it changes boring information into a colorful picture that boosts memory, enhances cognitive processes and sparks creativity (see Figure 1).

\section{Conclusion}

Mind mapping delivers significant benefits in vocabulary learning especially during the dry and boring online courses. It could change dull texts into colorful, highly organized and easy-to-memorize diagrams in ways that encourage students to participate and have a deeper understanding at the same time. During online classes, teachers could take advantage of online mind maps generator

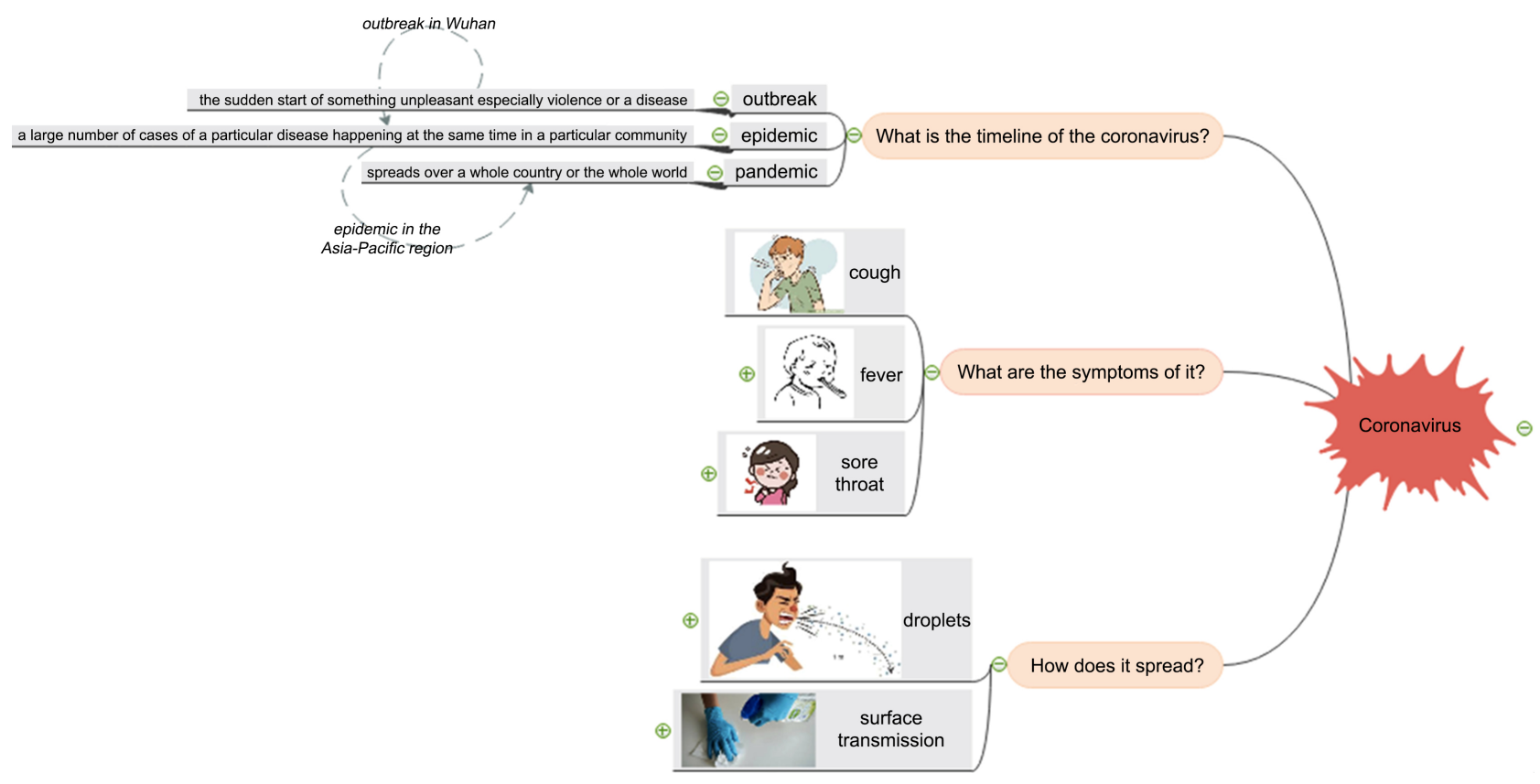

Figure 1. Mind map of coronavirus-related words. 
in order to brainstorm and generate discussions with the entire classroom. During the process of constructing a mind map, students could figure out how ideas are connected in the same way as how their brains work. As a visual information provider, it helps refocus their minds and foster better communication. Outside of class, the application of mind mapping lies in collaboration and comprehension. Students could be divided into several groups before revisiting the mind map. Together they might make more additions to the existing mind map and construct knowledge network of their own.

\section{Conflicts of Interest}

The author declares no conflicts of interest regarding the publication of this paper.

\section{References}

[1] Wang, Y. (2020) A Virus That Gave Birth to Many Netizens and Boosted Life Online. https://global.chinadaily.com.cn/a/202004/29/WS5ea8b984a310a8b241152759.html

[2] Yang, W. and Dai, W. (2011) Rote Memorization of Vocabulary and Vocabulary Development. English Language Teaching, 4, 61-64.

https://doi.org/10.5539/elt.v4n4p61

[3] Adodo, S.O. (2013) Effect of Mind-Mapping as a Self-Regulated Learning Strategy on Students' Achievement in Basic Science and Technology. Mediterranean Journal of Social Sciences, 4, 163-172. https://doi.org/10.5901/mjss.2013.v4n6p163

[4] Buzan, T. (1974) Using Both Sides of Your Brain. E. P. Dutton, New York.

[5] Buzan, T. (1993) The Mind Map Book. How to Use Radiant Thinking to Maximize Your Brain's Untapped Potential. Penguin Group, London.

[6] Steyvers, M. and Tenenbaum, J. (2005) The Large-Scale Structure of Semantic Networks: Statistical Analyses and a Model of Semantic Growth. Cognitive Science, 29, 41-78. https://doi.org/10.1207/s15516709cog2901_3

[7] Epidemic (2020) Oxford Online Dictionary. https://www.oxfordlearnersdictionaries.com/definition/english/epidemic_1?q=epid $\underline{\text { emic }}$

[8] Outbreak (2020) Oxford Online Dictionary. https://www.oxfordlearnersdictionaries.com/definition/english/outbreak?q=outbrea $\underline{\mathrm{k}}$

[9] Pandemic (2020) Oxford Online Dictionary. https://www.oxfordlearnersdictionaries.com/definition/english/pandemic_1?q=pan demic 